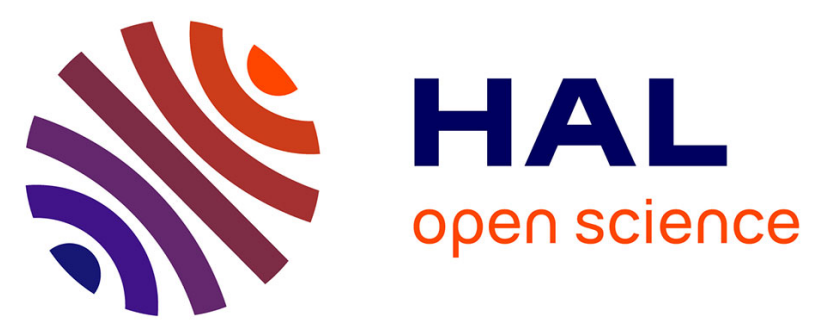

\title{
A new high temperature reactor for operando XAS: Application for the dry reforming of methane over $\mathrm{Ni} / \mathrm{ZrO} 2$ catalyst
}

Antonio F Aguilar-Tapia, Samy Ould-Chikh, Eric Lahera, Alain Prat, William Delnet, Olivier Proux, Isabelle Kieffer, Jean-Marie Basset, Kazuhiro

Takanabe, Jean-Louis Hazemann

\section{To cite this version:}

Antonio F Aguilar-Tapia, Samy Ould-Chikh, Eric Lahera, Alain Prat, William Delnet, et al.. A new high temperature reactor for operando XAS: Application for the dry reforming of methane over $\mathrm{Ni} / \mathrm{ZrO} 2$ catalyst. Review of Scientific Instruments, 2018, 89 (3), pp.035109. 10.1063/1.4998929 . hal-01874542

\section{HAL Id: hal-01874542 \\ https://hal.science/hal-01874542}

Submitted on 24 Nov 2021

HAL is a multi-disciplinary open access archive for the deposit and dissemination of scientific research documents, whether they are published or not. The documents may come from teaching and research institutions in France or abroad, or from public or private research centers.
L'archive ouverte pluridisciplinaire HAL, est destinée au dépôt et à la diffusion de documents scientifiques de niveau recherche, publiés ou non, émanant des établissements d'enseignement et de recherche français ou étrangers, des laboratoires publics ou privés. 


\title{
A new high temperature reactor for operando XAS: Application for the dry reforming of methane over $\mathrm{Ni} / \mathrm{ZrO}_{2}$ catalyst
}

\author{
Antonio Aguilar-Tapia, ${ }^{1,2, a)}$ Samy Ould-Chikh, ${ }^{1}$ Eric Lahera, ${ }^{3}$ Alain Prat, ${ }^{2}$ \\ William Delnet, ${ }^{3}$ Olivier Proux, ${ }^{3}$ Isabelle Kieffer, ${ }^{3}$ Jean-Marie Basset, ${ }^{1}$ \\ Kazuhiro Takanabe, ${ }^{1}$ and Jean-Louis Hazemann ${ }^{2}$ \\ ${ }^{1}$ King Abdullah University of Science and Technology (KAUST), KAUST Catalysis Center (KCC) \\ and Physical Sciences and Engineering Division (PSE), 4700 KAUST, Thuwal 23955-6900, Saudi Arabia \\ ${ }^{2}$ Institut Néel, UPR 2940 CNRS-Université Grenoble Alpes, F-38000 Grenoble, France \\ ${ }^{3}$ OSUG, UMS 832 CNRS-Université Grenoble Alpes, F-38041 Grenoble, France
}

(Received 3 August 2017; accepted 1 March 2018; published online 22 March 2018)

\begin{abstract}
The construction of a high-temperature reaction cell for operando X-ray absorption spectroscopy characterization is reported. A dedicated cell was designed to operate as a plug-flow reactor using powder samples requiring gas flow and thermal treatment at high temperatures. The cell was successfully used in the reaction of dry reforming of methane (DRM). We present $X$-ray absorption results in the fluorescence detection mode on a $0.4 \mathrm{wt} \% \mathrm{Ni} / \mathrm{ZrO}_{2}$ catalyst under realistic conditions at $750{ }^{\circ} \mathrm{C}$, reproducing the conditions used for a conventional dynamic microreactor for the DRM reaction. The setup includes a gas distribution system that can be fully remotely operated. The reaction cell offers the possibility of transmission and fluorescence detection modes. The complete setup dedicated to the study of catalysts is permanently installed on the Collaborating Research Groups French Absorption spectroscopy beamline in Material and Environmental sciences (CRG-FAME) and French Absorption spectroscopy beamline in Material and Environmental sciences at Ultra-High Dilution (FAME-UHD) beamlines (BM30B and BM16) at the European Synchrotron Radiation Facility in Grenoble, France. Published by AIP Publishing. https://doi.org/10.1063/1.4998929
\end{abstract}

\section{INTRODUCTION}

Heterogeneous catalysts commonly exhibit a variety of different surface sites that are difficult to identify. Identification of the active sites is critical for the design and development of improved catalytic materials. Ideally, characterization of a catalyst involves the measurement of its corresponding properties during the catalytic reaction, i.e., operando conditions. ${ }^{1}$ However, performing analytic measurements of the reaction process under realistic conditions is highly challenging. Currently, X-ray absorption spectroscopy (XAS) is one of the most widely used techniques for analysis of catalysts under reaction conditions due to the penetration depth of the highenergy X-rays, enabling adequate analysis of the electronic and structural properties of heterogeneous catalysts. Information regarding local coordination, symmetry, and oxidation states can be acquired from the X-ray absorption near edge structure (XANES) spectrum. Additional data such as coordination numbers, types of neighbors, interatomic distances, and disorder can all be determined using extended X-ray absorption fine structure (EXAFS) spectroscopy. Nevertheless, because the structure and electronic properties often change with the reaction conditions, it is highly desirable that the reaction kinetics can be simultaneously measured with the XAS to ensure a relevant structure-property relationship. ${ }^{2}$

A spectroscopic cell for studying the catalyst while it is working (operando) needs a completely different design than a cell for catalyst in situ conditions. ${ }^{3}$

\footnotetext{
a) Author to whom correspondence should be addressed: antonio.aguilar-tapia @ neel.cnrs.fr
}

Grunwaldt et $a .^{4}$ have described criteria to guide the development of in situ cells from the start of the construction to aim finally the "best compromise." alyst wafer (pressed pellet) placed in an environmental cell with gas flowing around the pellet shows its suitability for obtaining good spectral quality data with homogeneous beam transmission. Nevertheless, the use of pellets induces pore diffusion limitations. Authors mentioned that these negative effects can be eliminated by using macroporous materials as $\gamma$-alumina as a binder material (instead of low porosity material as boron nitride) which is not always possible without altering the catalytic properties of the sample material. Other way to overcome diffusion problems is the use of small grains of catalyst (sieved catalyst powder) especially in the case of fast catalytic reactions.

One of the first cells for the in situ XAS studies of catalysts was designed by Lytle et al. ${ }^{5}$ The design has been adopted by many research groups, and it is one of the few commercially available cells. ${ }^{6}$ It allows transmission measurements on both self-supporting wafers and powders using a special boat-type inset. An additional ion chamber detector with a built-in amplifier is available for measurements in the fluorescence mode. The gas atmosphere may be changed and the cell can be evacuated. The maximum pressure is rated up to 100 bars. It is possible to cool the sample holder with liquid nitrogen and to heat up to approximately $1000 \mathrm{~K}$ using a built-in resistance heating unit. At the same time, the outer shell of the cell is water-cooled to prevent heating of the beamline components and the fluorescence detector. One downside of the design is the gas bypassing the sample and thus preventing the acquisition of quantitative catalytic data. The other drawback is that 
the regulation of the temperature is not performed close to the catalyst sample but on the furnace. A significant improvement of the same general layout was reported by Hannemann et al. ${ }^{7}$ This cell allows measurements on powders (similar to the cell by Bazin $e t a l .{ }^{8}$ ) and self-supported wafers (pressed into the sample compartment). It mimics a plug-flow reactor, and it can be used on both gas and liquid environments. Additionally it allows the products' online analysis. The sample holder further allows cooling down to the temperature of liquid nitrogen and heating to $973 \mathrm{~K}$. The inner volume of the cell can be evacuated (e.g., to prevent ice formation on the $\mathrm{X}$-ray windows during measurements at liquid nitrogen temperature) or filled with $\mathrm{He}$ for measurements at low energies. Different materials can be used for the sample holder depending on the photon energy, pressure, and chemical nature of reactants/products. The thickness of the sample can be varied by using reaction cell insets of various sizes.

A much simpler but not less versatile cell was originally suggested by Clausen and Topsøe $\mathrm{e}^{9}$ and Sankar et al. ${ }^{10}$ and further developed by Grunwaldt et al. ${ }^{4}$ The concept is based on a thin quartz (or glass) capillary (0.5-3 mm o.d. and 10-20 $\mu \mathrm{m}$ wall thickness) connected to a gas dosing and a gas analysis unit by means of graphite ferrules ${ }^{4}$ or high-temperature epoxy glue for gas-tight sealing. ${ }^{11}$ The catalyst, in the form of small grains (grain size is typically within $50-150 \mu \mathrm{m}$ range), is placed between two quartz wool plugs, and the overall assembly has a geometry of a regular plug-flow catalytic reactor with virtually no dead volume. The capillary can be heated by gas stream blowers, e.g., a gas blower built by Cyberstar S.A. (now by FMB-Oxford, heating up to $1273 \mathrm{~K}$ ). ${ }^{12}$ The remarkable versatility of this design allows simultaneous measurements of $\mathrm{X}$-ray absorption, fluorescence, diffraction, ${ }^{13}$ and also optical spectroscopy such as Raman ${ }^{13,14}$ or UV-Vis. ${ }^{15}$ The capillary microreactor cell is also suitable for studies of photocatalysts under working conditions. ${ }^{16}$ Catalytic data can be measured and evaluated as for any conventional plug-flow reactor. There are certain drawbacks of the design, which should be taken into account when planning an experiment. First of all, precise measurement of the catalyst temperature is not possible; second, as for all plug-flow reactors, in the case of fast reactions, concentration gradients along the catalyst bed will occur. ${ }^{17}$ Furthermore, although the cell was tested under pressures up to 50 bars, ${ }^{9}$ the actual maximum pressure depends on the particular capillary and cannot be defined $a$ priori.

Additionally, there have been more recent designs with the goal of characterizing the catalyst and its catalytic performance at the same time. Bare et al. ${ }^{18}$ described a plug-flow reactor made of beryllium tubes with $3 \mathrm{~mm}$ outer diameter and $0.5-0.75 \mathrm{~mm}$ wall thickness. This design allows the measurement of reaction kinetics under realistic reaction conditions (up to $600{ }^{\circ} \mathrm{C}$ and 14 bars) while simultaneously obtaining XAS data in the transmission mode through the walls of the beryllium reactor. One advantage of the reported design is the possibility of directly measuring the temperature of the catalyst bed since the reactor is thick enough to accommodate a thermocouple. The other advantage is that due to the low $\mathrm{X}$-ray absorption by the beryllium wall collection the acquisition of XAS data is possible below $5 \mathrm{keV}$. However, a beryllium reactor is costly and challenging to operate because it may present health risks if handled improperly. The inhalation of beryllium-containing dust, mist, or fumes can cause serious lung conditions since it is reported to be a carcinogen via inhalation. ${ }^{19}$

Complementing the aforementioned efforts, recently there has been more interest in improving the capabilities of these reactors focusing on the design of XAS cells to perform operando characterization by using low absorbing materials as polyamide tubular reactors. ${ }^{2}$ This cell allows transmission and fluorescence detection and is able to operate at temperatures as high as $300{ }^{\circ} \mathrm{C}$ and pressures of up to 3.5 bars. The reaction cell was adapted to combine XAS and Raman measurements using a fused silica capillary able to operate up to 200 bars and $280{ }^{\circ} \mathrm{C},{ }^{20}$ nevertheless, the authors reported the bending of the capillary by the temperature effect, resulting in signal/noise changes due to the beam that was almost out of the capillary because of the bending.

In a previous design from the Néel Institute from the Centre National de la Recherche Scientifique (CNRS), a highpressure/high-temperature autoclave was developed to reproduce the experimental conditions relevant to geological fluids using X-ray absorption and Raman spectroscopies. ${ }^{21}$ One of the main features of the cell is that the temperature and the pressure are varied independently in the ranges of $30-1700{ }^{\circ} \mathrm{C}$ and 1-2000 bars. Furthermore, the versatility of this setup allows the study of aqueous solutions $\left(\mathrm{T} \leq 500{ }^{\circ} \mathrm{C}\right.$ and $\mathrm{P} \leq 2000$ bars $)$ and liquid metals and glasses $\left(\mathrm{T} \leq 1700{ }^{\circ} \mathrm{C}\right.$ and $\mathrm{P} \leq 2000$ bars). The internal container was selected to be glassy carbon due to its chemical neutrality with the sample, its low absorption properties, its resistance to high temperatures, and its compatibility with easy machining.

There are some reports in the literature using glassy carbon, e.g., as a working electrode in electrochemistry but just one report on the use of a glassy carbon reactor for XAS characterization for high temperature catalysis. ${ }^{22} \mathrm{~A}$ glassy carbon tube was used for the operando XAS characterization of the $\mathrm{Cu} /$ zeolite catalyst in the selective reduction of $\mathrm{NO}_{\mathrm{x}}$ by $\mathrm{NH}_{3}$. The tests were performed with a maximum temperature of $300{ }^{\circ} \mathrm{C}$; nevertheless, the maximum operational temperature is not specified. The XAS cell used presents two configurations for each detection mode. ${ }^{2}$ For transmission measurements, the heating block comprises two $0.25 \mathrm{in}$. holes in the beam path allowing the X-ray beam to reach the sample. In the second configuration, the heating block is modified using an independent attachable piece with a 0.25 in. hole perpendicular to the beam for fluorescence detection. Even if validation for transmission detection was performed, no validation by the fluorescence experimental spectrum was reported. The gas inlet and outlet were attached to the carbon tube reactor above and below the heating block by compression fittings. The authors reported that the tube with a 1-mm-thick wall had a high transmittance and could be used to measure the K edge above $\sim 6$ $\mathrm{keV}$ or the $\mathrm{K}$-edge for $\mathrm{Mn}, \mathrm{Fe}, \mathrm{Co}, \mathrm{Ni}, \mathrm{Cu}$, and some rare earth elements.

Our setup is derived from the previous high-pressure/hightemperature cell available on the FAME beamline mentioned earlier. ${ }^{21}$ Therefore, it is possible to operate at high temperatures (up to $1000{ }^{\circ} \mathrm{C}$ ). The design ensures a homogeneous heating in the catalytic bed region which is important for the study of catalyst under operando conditions. The optimization 
of our setup offers a safer handling of the device in comparison with systems using gas blower heaters. The heating part of our cell is isolated from the ambient, so the body of the cell remains cold which allows a safe handling and the possibility to approach detectors near to the cell which is important to improve the signal detection by fluorescence in diluted samples. One of the main characteristics of our cell is the X-ray fluorescence window (perpendicular to the beam) allowing simultaneously transmission and fluorescence detections. It is a versatile configuration to analyze concentrated and diluted samples. Spatially resolved studies can be performed because the $290 \times 100 \mu \mathrm{m}(\mathrm{H} \times \mathrm{V}$, FWHM) beam spot delivered by the beamline can be moved along the vertical axis of the reactor. The glassy carbon reactor was machined from its original wall thicknesses of $1 \mathrm{~mm}$ to $350 \mu \mathrm{m}$ allowing most of the $\mathrm{X}$-ray beams to be transmitted to the sample ( $\sim 82 \%$ of the beams transmitted at the Ni K-edge). Good data quality can be achieved because of the low absorption of glassy carbon, which also offers higher thermal resistance and strength than do borosilicate or polyamide reactors. Moreover, glassy carbon is easy to use and does not pose any risk to health compared to the beryllium reactors. The reactor was connected to the gas inlet (upper part) and outlet (lower part) tubes using epoxy resin to ensure the sealing of the cell and avoiding the use of fittings that can induce stress to the tube and gas leaking.

The ability to conduct accurate XAS measurements at high temperatures is of a great interest for a variety of reaction processes, enabling deep understanding of catalytic behaviors throughout different stages of the reaction. An example of such processes is the dry reforming of methane (DRM), which is an endothermic reaction $(\Delta \mathrm{H}=+247 \mathrm{~kJ} / \mathrm{mol})$ and which therefore requires high temperatures to attain high equilibrium conversions. $^{23,24}$ The DRM is an important industrial reaction because it involves the use of two of the most destructive greenhouse gases, methane and carbon dioxide, to produce synthesis gas $\left(\mathrm{CH}_{4}+\mathrm{CO}_{2} \rightarrow 2 \mathrm{CO}+2 \mathrm{H}_{2}\right)$.

In this work, we describe the design of a new high temperature reactor for operando XAS, which offers the capability of using fluorescence and transmission detection modes. The reaction cell includes a plug-flow reactor made from glassy carbon which allows almost all of the X-rays to be transmitted to the sample. To validate our final design, the reaction cell was used for the characterization of a low metal loading $\mathrm{Ni} / \mathrm{ZrO}_{2}$ powder catalyst in the DRM reaction under realistic conditions $\left(750{ }^{\circ} \mathrm{C}\right)$. The reaction system includes a fully remote-controlled gas distribution system. The performance of the reaction cell was validated by comparing it with the catalytic results obtained in a conventional dynamic microreactor (PID Eng \& Tech) using the same conditions. The complete setup dedicated for the study of catalysts is now installed on the CRG-FAME beamlines (BM30B and BM16) at the European Synchrotron Radiation Facility (ESRF) in Grenoble, France.

\section{DESCRIPTION OF THE XAS CELL}

The XAS reaction cell was designed to perform dynamic reaction using powder samples which requires gas flow and thermal treatment in order to reproduce the high-temperature real conditions in a conventional dynamic microreactor. Figure 1(a) shows a 3D layout of the components of the cell. The glassy carbon tube is located in the middle of the heating elements, and the design uses a thermocouple to control the temperature of the oven and a second thermocouple is located close to the sample. Figure 1(b) shows a photograph of the assembled reaction cell on the beamline ready for operation; the image shows one of the two transmission windows as well as the fluorescence window. The body of the cell was built using stainless steel.

\section{A. Reactor}

Gases travel to the catalytic bed by flowing from the top to the bottom through an innovative plug-flow reactor made of a vitreous carbon tube produced by Hochtemperatur-Werkstoffe (HTW), GmbH. The tube is non-porous and high-temperature resistant (up to $3000^{\circ} \mathrm{C}$ under inert gas or vacuum, over $600^{\circ} \mathrm{C}$ in oxidizing atmospheres). Please refer to the vendor website for further information. ${ }^{25}$ The tube was machined in the window zone from its original wall thickness of $1 \mathrm{~mm}$ to $350 \mu \mathrm{m}$ (see Fig. S1 of the supplementary material) allowing most of the X-ray beams to be transmitted to the sample, $\sim 82 \%$ of the beams transmitted at the Ni K-edge. This is convenient if comparing $92 \%$ and $84 \%$ of the transmitted beams for a 10 and
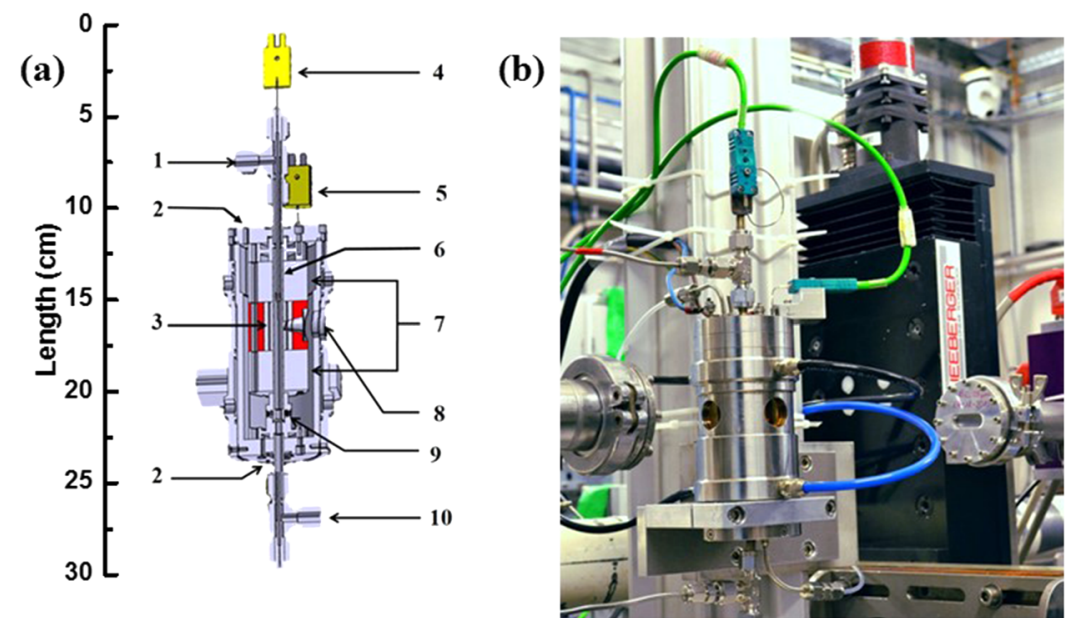

FIG. 1. (a) 3D layout of the reaction cell setup: (1) inlet of the gases to the cell, (2) plugs that allow He flow, (3) heating elements, (4) sample thermocouple inside the carbon tube, (5) thermocouple to the heating system, (6) vitreous carbon tube, (7) plugs which allows the water cooling circulation, (8) one of three Kapton windows, (9) bellows and (10) gas outlet; (b) real view of the fully assembled reactor on the beamline ready for operation. 
$20 \mu \mathrm{m}$ wall thickness, respectively, in conventional quartz capillaries at the same energy. It is also possible to use an $\mathrm{Al}_{2} \mathrm{O}_{3}$ tube or quartz tube in cases where the catalyst materials are not compatible with the carbon reactor; nevertheless, the X-rays transmitted to the sample could be compromised because of the absorption of these materials.

In brief, the reactor was connected to the gas inlet tube (upper part) using the Duralco ${ }^{\mathrm{TM}} 4703$ epoxy resin and to the outlet tube (lower part) by a bellows in the internal part of the cell. Both the upper and the lower tubes were attached to the body of the cell using the same epoxy resin to ensure the sealing of the cell. A Swagelok "tee" in the lower tube holds a metallic support holding the quartz wool of the catalytic bed. The reactor is filled in the upper part, and the powder is gently pressed. The "tee" in the upper tube holds the thermocouple in place close to the sample. At the end of the test, the sample is recovered, the reactor is cleaned with ethanol, and then it is ready to be refilled with a new sample for a new experiment.

\section{B. Heating elements}

The design of the heating elements was based on that developed by Tamura et al. ${ }^{26}$ It consists of placing the reactor in a $30 \mathrm{~mm}$ molybdenum tube [3 in Fig. 1(a)] heated to the experimental temperature with a resistive molybdenum metallic wire. A K-type thermocouple is placed inside the reactor to regulate the temperature as close as possible to the sample. A second thermocouple is housed in a hole drilled in the molybdenum tube in order to measure the temperature of the heating system. All these elements are confined in insulating ceramic elements to avoid heat outflow. The design of the cell allows operation from room temperature to elevated temperatures up to $1000{ }^{\circ} \mathrm{C}$ (see Fig. S2 of the supplementary material). The oxidation of the carbon tube and the molybdenum wires is prevented either by external ultra-pure He flow or a static $\mathrm{He}$ pressure of 1 bars. The control of the temperature was performed by PID. After tuning the parameters in the control system, it was possible to heat from room temperature (RT) to $750{ }^{\circ} \mathrm{C}$ using a heating rate of $10^{\circ} \mathrm{C} / \mathrm{min}$ with a negligible deviation during the ramp, and then the temperature was held for more than $10 \mathrm{~h}$ with a deviation of $\pm 0.66^{\circ} \mathrm{C}$, until finally, the controller was allowed to modify the ramp, and the cell was cooled to RT at a rate of $100{ }^{\circ} \mathrm{C} / \mathrm{min}$.

\section{Window materials and arrangement}

Figure 2 displays a 3D layout of the window arrangement and a real view of the cell installed on the beamline. The cell was designed to operate in both transmission (see the supplementary material) and fluorescence detection modes, and the design therefore involves two windows in the beam axis for the collection of transmission spectra and a third window at $90^{\circ}$ for the collection of the fluorescence spectra. The windows were made of Kapton and were $25 \mu \mathrm{m}$ thick and $19 \mathrm{~mm}$ in diameter to enable a high transmittance to $\mathrm{X}$-rays.

To protect the windows from heating, the cell is cooled by circulation of water. Considering that the sample is located at the center of the heating zone, all heating elements have three 5-mm-diameter apertures allowing the X-ray photons to pass through. This configuration also allows vertical measurements
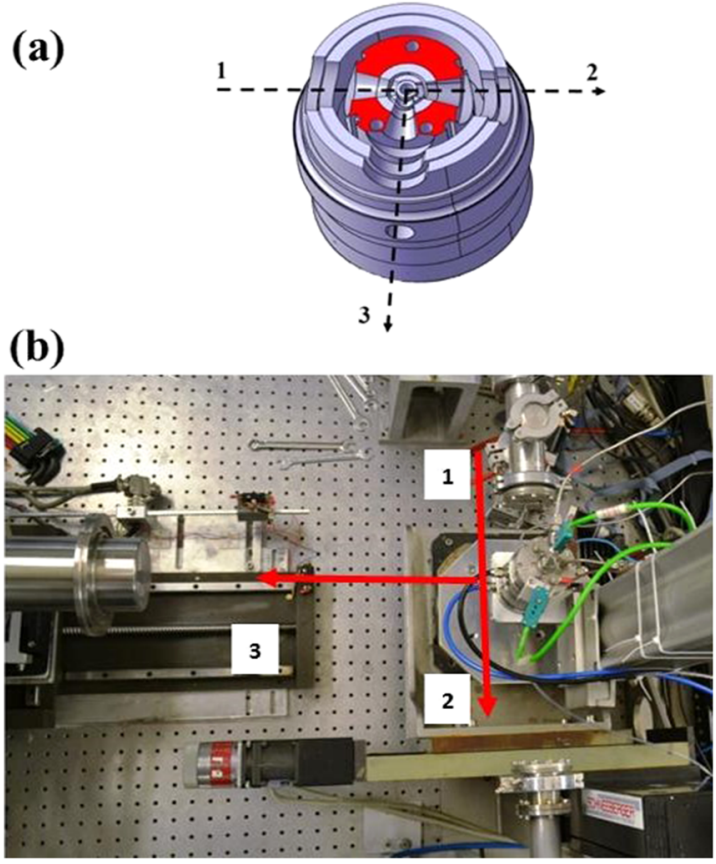

FIG. 2. (a) 3D layout of the general window geometry, which allows the path from (1) the beamline to the (2) transmission or (3) fluorescence detector; (b) top view of the cell on the beamline; the transmission path and the fluorescence detector can be observed.

of chemical inhomogeneity of the catalytic bed $(\sim 4 \mathrm{~mm})$ because the $290 \times 100 \mu \mathrm{m}(\mathrm{H} \times \mathrm{V}$, FWHM) beam spot delivered by the beamline can be moved along the vertical axis of the reactor. This is of a particular importance when the reactor is operated at high reactant conversion because the gaseous composition at the inlet becomes substantially different from that at the outlet of the reactor.

\section{Gas distribution setup and gas analysis}

A completely automated gas distribution system from Serv' Instrumentation (Fig. S4 of the supplementary material) was used to deliver a mixture of gases through the reaction cell and the venting system. The system allows complete remote control of the gas distribution using a PC (personal computer). Each gas line was controlled by mass flow controllers calibrated for each gas with a broad range of volumetric flow. The DRM gas composition was as follows: $10 \% \mathrm{CO}_{2}, 10 \%$ $\mathrm{CH}_{4}$, and $80 \%$ of a gas vector consisting of a $1 \% \mathrm{Ar}: \mathrm{He}$ mixture (Ar was used as the internal standard). The setup includes a pressure valve that protects the vitreous carbon tube from an unusual increase in pressure that could break the reactor. In addition, a four-way valve allows the switch between a by-pass line and the line to the reaction cell. All high-purity gases used were provided by Air liquid France. In addition, Gas Clean oxygen moisture and hydrocarbon filters from Agilent were used to diminish the impurities at maximum.

The gas composition from the reactor was monitored on-line by an EcoCat-P portable mass spectrometer system from European Spectrometry Services (ESS) that can be operated remotely. The system is equipped with two identical capillary inlets for the on-line analysis of the reactor outlet and a bypass line. The response time of the 
inlet is $150 \mathrm{~ms}$. The system also allows quantitative analysis and has the capability to monitor up to 64 species in real time. In addition, the mass spectrometer also identifies unknown compounds and offers detection levels down to ppb levels.

\section{EXPERIMENTAL}

\section{A. Longitudinal temperature profile in the heating zone}

A temperature profile test along the $30 \mathrm{~mm}$ oven [3 in Fig. 1(a)] was performed using different He flows (10, 30, 50, $80,100,150$, and $200 \mathrm{ml} / \mathrm{min}$ ) while keeping two different set points constant $\left(300\right.$ and $\left.750{ }^{\circ} \mathrm{C}\right)$. To perform the test, the thermocouple of the heating system [5 in Fig. 1(a)] was used to control the temperature, and the sample thermocouple [4 in Fig. 1(a)] was used to measure the temperature at different positions along the oven.

Figure 3 shows the temperature profile along the oven using different He flows. The shaded area represents the sample position. It can be observed that the gas is heated in the first $10 \mathrm{~mm}$ of the oven at both temperature set points just before the $5 \mathrm{~mm}$ aperture. Then, the temperature remains constant independent of the gas flow. As mentioned before, considering that the sample is located at the center of the heating elements and the size of the analyzable catalytic bed is $\sim 5 \mathrm{~mm}$ (i.e., at 12-17 $\mathrm{mm}$ position of the oven), these results confirm that the region where the sample is located is homogeneously heated independent of the gas flow. The oven of our reaction cells ensures a homogeneous temperature profile along the catalytic bed which is important for the study of catalyst under operando conditions.

\section{B. Blank tests}

The tests were performed using the same conditions as used in a conventional dynamic microreactor (PID Eng \& Tech) for the DRM reaction. The cell was first tested empty and then with the $\mathrm{ZrO}_{2}$ support (50 $\mathrm{mg}$ of $\mathrm{ZrO}_{2}$ sieved in the 250-300 $\mu \mathrm{m}$ size range). The cell was heated from room temperature (RT) to $750{ }^{\circ} \mathrm{C}\left(10^{\circ} \mathrm{C} / \mathrm{min}\right)$ under a flow of $4 \% \mathrm{H}_{2} / \mathrm{He}$. Then, the reaction mixture consisting of $\mathrm{CO}_{2}: \mathrm{CH}_{4}: 1 \% \mathrm{Ar} / \mathrm{He}$
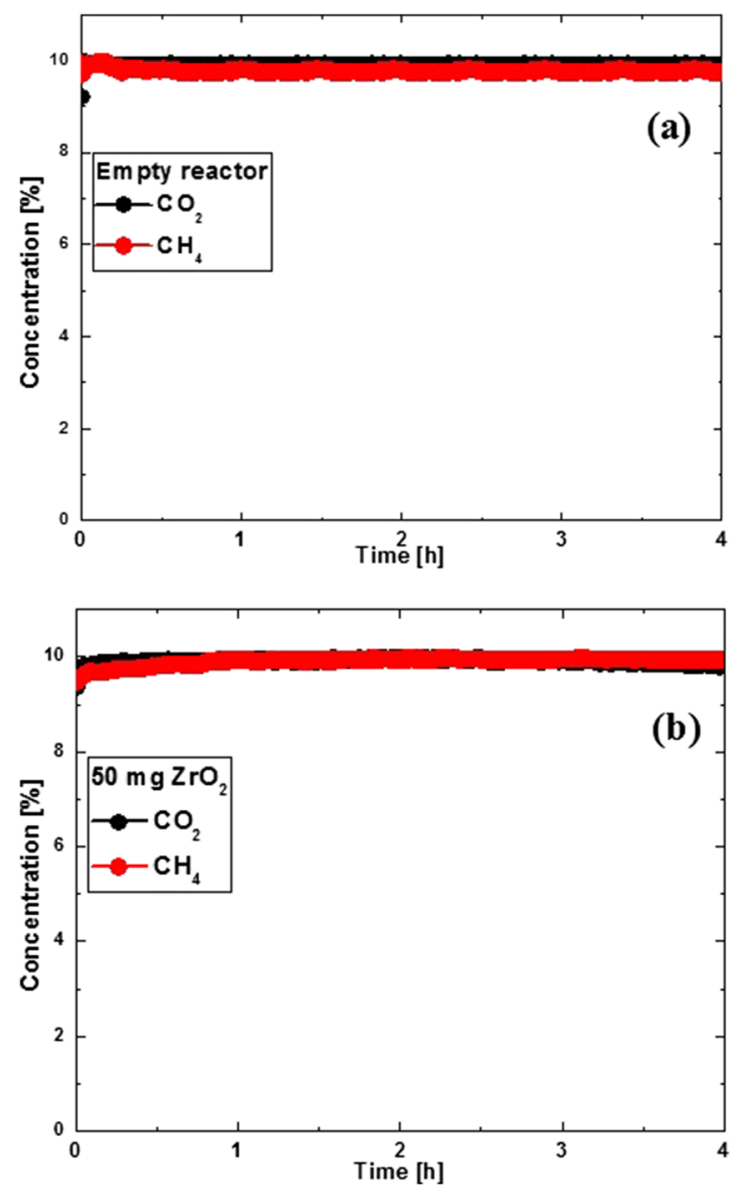

FIG. 4. Evolution of volumetric concentrations of $\mathrm{CO}_{2}$ and $\mathrm{CH}_{4}$ as a function of time at $750{ }^{\circ} \mathrm{C}$ (a) in an empty reactor and (b) with a $\mathrm{ZrO}_{2}$ catalyst support.

(1:1:8) $(100 \mathrm{ml} / \mathrm{min})$ was introduced into the cell, and the concentrations of the gases were monitored by mass spectrometry. Figure 4 shows the evolution of the volumetric concentrations of $\mathrm{CO}_{2}$ and $\mathrm{CH}_{4}$ as a function of time at $750{ }^{\circ} \mathrm{C}$, and it can be seen that after $4 \mathrm{~h}$, the concentrations of $\mathrm{CO}_{2}$ and $\mathrm{CH}_{4}$ remain constant without (a) and with the $\mathrm{ZrO}_{2}$ support (b). We confirmed that the $\mathrm{ZrO}_{2}$ support and the carbon vitreous reactor are inert under DRM conditions.
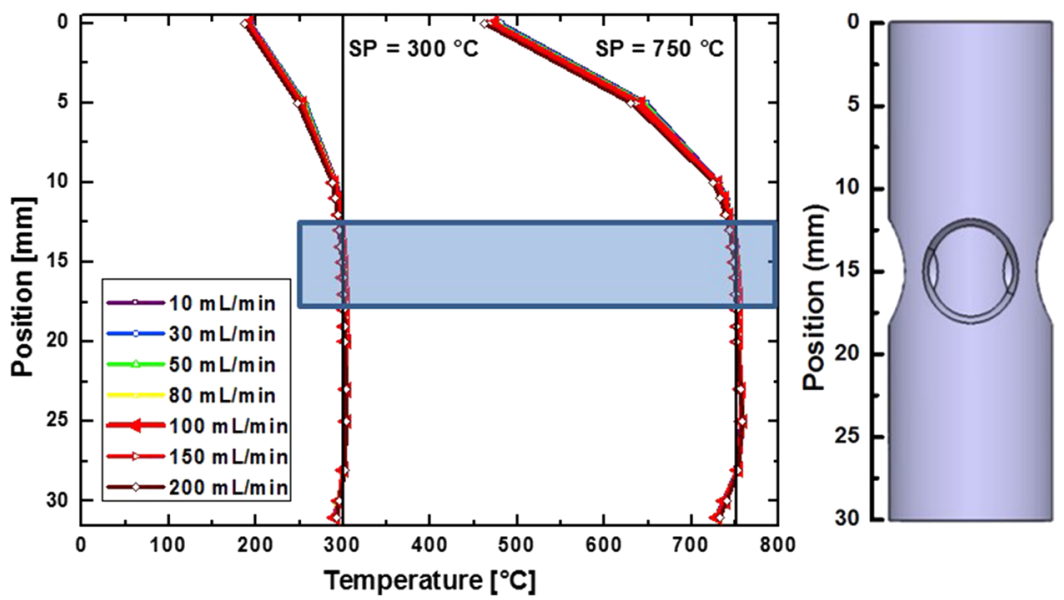

FIG. 3. Temperature profile along the heating elements at $\mathrm{SP}=300$ and $750{ }^{\circ} \mathrm{C}$ with different gas flows; the shaded area represents the sample position (left) and 3D layout of the $30 \mathrm{~mm}$ oven (right). 


\section{Comparison of a catalytic test performed with a microreactor and with the XAS cell}

A Ni/ZrO $2(0.4$ wt. \% Ni) catalyst was used to validate the performance of the reaction cell in the dry reforming of methane. The catalyst was prepared by the homogeneous deposition precipitation method. ${ }^{27}$ Briefly, $3.39 \mathrm{ml}$ of a $0.05 \mathrm{M}$ metal precursor solution $\left(\mathrm{NiCl}_{2} 6 \mathrm{H}_{2} \mathrm{O}, 99.999 \%\right.$ from Aldrich) was placed into a solution containing urea under stirring. Then, $2 \mathrm{~g}$ of $\mathrm{ZrO}_{2}$ as support (from Aldrich, pre-calcined at $850{ }^{\circ} \mathrm{C}$ for $20 \mathrm{~h}$ ) was added and stirred at $90^{\circ} \mathrm{C}$ for $1 \mathrm{~h}$ under Ar. Then, $100 \mathrm{ml}$ of ethylene glycol was added to the solution and stirred at $150{ }^{\circ} \mathrm{C}$ for $3 \mathrm{~h}$. Then, the sample was washed filtering with $600 \mathrm{ml}$ of de-ionized water and $100 \mathrm{ml}$ of ethanol. Finally, the sample was dried overnight in an oven at $60{ }^{\circ} \mathrm{C}$. The validation of the XAS cell was performed with the following procedure:

First, $40 \mathrm{mg}$ of $0.4 \mathrm{wt} \% \mathrm{Ni} / \mathrm{ZrO}_{2}$ catalyst (sieved in the $250-300 \mu \mathrm{m}$ size range) was introduced as a packed bed into the reactor and purged with a $1 \% \mathrm{Ar} / \mathrm{He}$ flow at RT. Then, $4 \% \mathrm{H}_{2} / \mathrm{He}$ was flowed into the reactor and heated up to $750{ }^{\circ} \mathrm{C}$ using a heating ramp of $10{ }^{\circ} \mathrm{C} / \mathrm{min}$ followed by a $1 \mathrm{~h}$ plateau at the same temperature. After the thermal treatment, the reactor was purged with a $1 \% \mathrm{Ar} / \mathrm{He}$ flow, and then the reaction mixture $\mathrm{CO}_{2}: \mathrm{CH}_{4}: 1 \% \mathrm{Ar} / \mathrm{He}(1: 1: 8)$ $\left(\mathrm{GHSV}=120 \mathrm{lg}^{-1} \mathrm{~h}^{-1}\right.$ ) was flowed into the cell, and the products of the reaction were tracked by mass spectrometry on-line.

The four-way valve fitted in the gas distribution system allows the preparation of the gas mixture in the bypass line prior to the start of the reaction. The gas vector mixture consisting of $1 \% \mathrm{Ar}$ (internal standard) in $\mathrm{He}$ was chosen to quantify the variation of the flow rate due to the stoichiometry of the reforming reaction. Practically, this was performed using mass spectrometry and by monitoring the stabilization of current intensities corresponding to $\mathrm{m} / \mathrm{z}=15$ $\left[\mathrm{I}\left(\mathrm{CH}_{4}\right)_{\mathrm{i}}\right], \mathrm{m} / \mathrm{z}=44\left[\mathrm{I}\left(\mathrm{CO}_{2}\right)_{\mathrm{i}}\right]$, and $\mathrm{m} / \mathrm{z}=40\left[\mathrm{I}(\mathrm{Ar})_{\mathrm{i}}\right]$ for $\mathrm{CH}_{4}, \mathrm{CO}_{2}$, and Ar gases, respectively. The amounts of reacted methane and carbon dioxide were assessed by following the current intensities corresponding to $\mathrm{m} / \mathrm{z}=15\left[\mathrm{I}\left(\mathrm{CH}_{4}\right)_{\mathrm{f}}\right]$ and $\mathrm{m} / \mathrm{z}=44\left[\mathrm{I}\left(\mathrm{CO}_{2}\right)_{\mathrm{f}}\right]$ at the reactor outlet. Thus, the conversions for methane $\left[\mathrm{X}\left(\mathrm{CH}_{4}\right)\right]$ and carbon dioxide $\left[\mathrm{X}\left(\mathrm{CO}_{2}\right)\right]$ were calculated during the reaction using the following equations:

$$
\begin{aligned}
& \mathrm{X}\left(\mathrm{CH}_{4}\right)(\%)=\left[1-\left(\frac{\mathrm{I}\left(\mathrm{CH}_{4}\right)_{\mathrm{f}}}{\mathrm{I}\left(\mathrm{CH}_{4}\right)_{\mathrm{i}}}\right)\left(\frac{\mathrm{I}(\mathrm{Ar})_{\mathrm{i}}}{\mathrm{I}(\mathrm{Ar})_{\mathrm{f}}}\right)\right] * 100, \\
& \mathrm{X}\left(\mathrm{CO}_{2}\right)(\%)=\left[1-\left(\frac{\mathrm{I}\left(\mathrm{CO}_{2}\right)_{\mathrm{f}}}{\mathrm{I}\left(\mathrm{CO}_{2}\right)_{\mathrm{i}}}\right)\left(\frac{\mathrm{I}(\mathrm{Ar})_{\mathrm{i}}}{\mathrm{I}(\mathrm{Ar})_{\mathrm{f}}}\right)\right] * 100 .
\end{aligned}
$$

Figures 5(a) and 5(b) show the conversion of $\mathrm{CO}_{2}$ and $\mathrm{CH}_{4}$ as a function of time at $750{ }^{\circ} \mathrm{C}$, respectively. The results obtained using the reaction XAS cell at ESRF were quite similar to the ones obtained in the microreactor, i.e., the $\mathrm{CO}_{2}$ and $\mathrm{CH}_{4}$ conversion levels together with the deactivation trends are very similar. Thus, the results obtained with the laboratory microreactor were reproduced using the
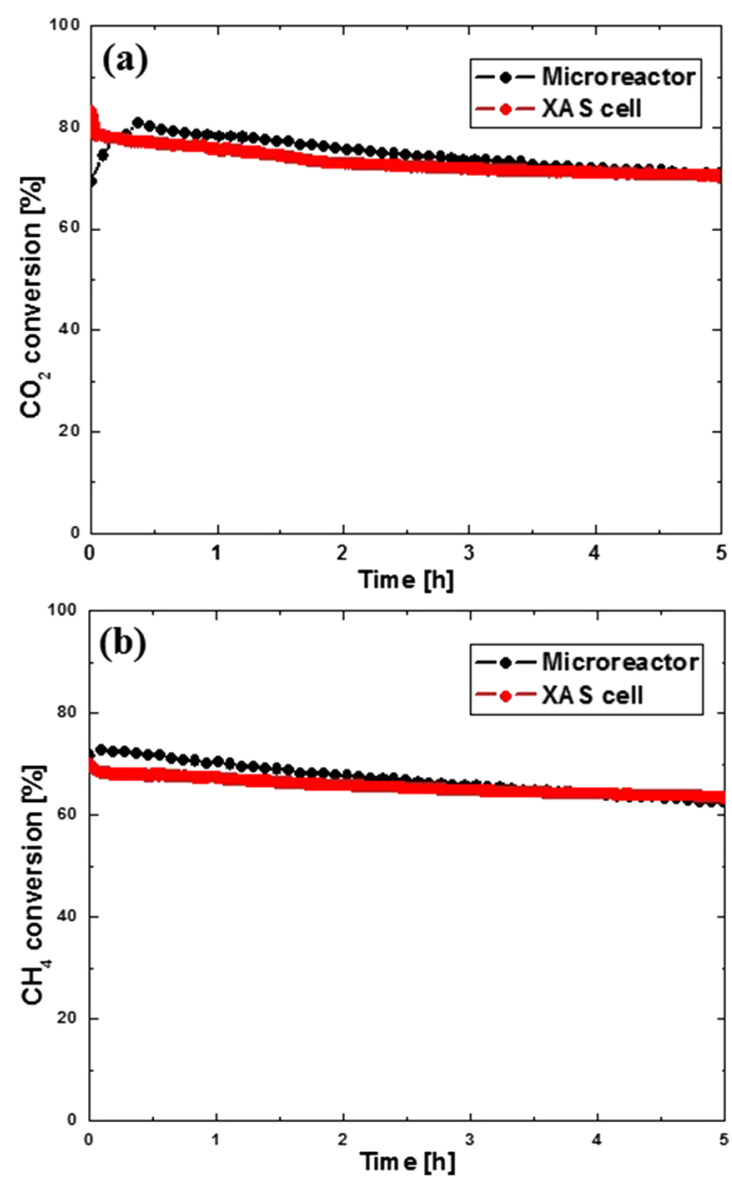

FIG. 5. Comparison of (a) $\mathrm{CO}_{2}$ conversion and (b) $\mathrm{CH}_{4}$ conversion using a microreactor and the XAS cell.

newly designed reaction cell, revealing the appropriate performance of all components of the reaction system. The reaction setup was validated and was ready for use in operando XAS characterizations.

\section{Operando XAS during dry reforming of methane}

The operando XAS characterization was performed according to the following protocol: First, $50 \mathrm{mg}$ of the $\mathrm{Ni} / \mathrm{ZrO}_{2}$ catalyst (sieved in the $250-300 \mu \mathrm{m}$ size range) was introduced as a packed bed into the reactor. XAS spectra were recorded under inert gas at room temperature in order to characterize the initial state of the catalyst. Then, a flow of $4 \% \mathrm{H}_{2} / \mathrm{He}$ was introduced at a $100 \mathrm{ml} / \mathrm{min}$ flow rate into the cell and heated up to $750{ }^{\circ} \mathrm{C}$ at $10^{\circ} \mathrm{C} / \mathrm{min}$, followed by a $1 \mathrm{~h}$ plateau at the same temperature. During the heat treatment, XANES spectra were recorded continuously to observe the change in the metal oxidation state. After the reduction step, the reactor was purged with the gas vector at $750{ }^{\circ} \mathrm{C}$. The reaction mixture $\mathrm{CO}_{2}: \mathrm{CH}_{4}: 1 \% \mathrm{Ar} / \mathrm{He}(1: 1: 8)$ was subsequently introduced at a total flow rate of $100 \mathrm{ml} / \mathrm{min}$ (GHSV $=1201 \mathrm{~h}^{-1} \mathrm{~g}^{-1}$ ) and the evolution of the concentration followed by $10 \mathrm{~h}$.

The structure of the metal nanoparticles was initially tracked by XANES spectroscopy to capture the fastest structural changes. Once the differences recorded in a series of XANES spectra were estimated to be minor, the 
characterization of the metal nanoparticles was supplemented by the acquisition of EXAFS spectra. The reaction was stopped after $10 \mathrm{~h}$, and the last three EXAFS spectra were merged to compare the final state of the catalysts.

XAS spectra at the Ni K-edge $(8333 \mathrm{eV})$ were obtained at the European Synchrotron Radiation Facility (Grenoble, France) on the CRG-FAME beamline (BM30B). The ring was operated at $6 \mathrm{GeV}$ with a nominal current of $200 \mathrm{~mA}$ in the $7 / 8+1$ mode. The beamline was equipped with a liquidnitrogen-cooled double-crystal $\mathrm{Si}(220)$ monochromator surrounded by two Rh-coated mirrors for harmonic rejection. The beam size on the sample was $290 \times 100 \mu \mathrm{m}(\mathrm{H} \times \mathrm{V}$, FWHM). The spectra were recorded at the nickel K-edge in the fluorescence mode using a CANBERRA 30-element Ge solidstate detector. The monochromator was energy-calibrated by measuring the nickel $\mathrm{K}$ absorption edge using a metallic nickel foil. For fluorescence measurements, the incident beam was positioned close to the carbon wall in front of the fluorescence window in order to minimize the re-absorption of the fluorescence signal and to maximize the detected signal.

Special attention has to be given in the preparation of the catalytic bed to ensure good quality XAS spectra. It was noticed that it is necessary to gently press the powder after filling the reactor to obtain a uniform catalytic bed. Otherwise a non-uniform catalytic bed leads to bad quality spectra. Other point to consider is that the reactor is able to work up to 1 bar of relative pressure. An important problem during DRM reaction is coke formation through dissociation of methane and/or Boudouard reaction. Formation of coke may cause clogging of the reactor. In addition, an excess of pressing during the preparation of the catalytic bed could lead to a "plug" effect which could increase the internal pressure.

\section{E. Qualitative analysis}

Ni K-edge XANES spectra (Fig. 6) of the as-synthetized sample under He at RT show a weak peak in the preedge region due to the $1 \mathrm{~s} \rightarrow 3 \mathrm{~d}$ quadrupolar transitions, and the intense white lines are characteristic of the oxidized state of nickel located in an octahedral environment $(\mathrm{NiO}){ }^{28,29}$

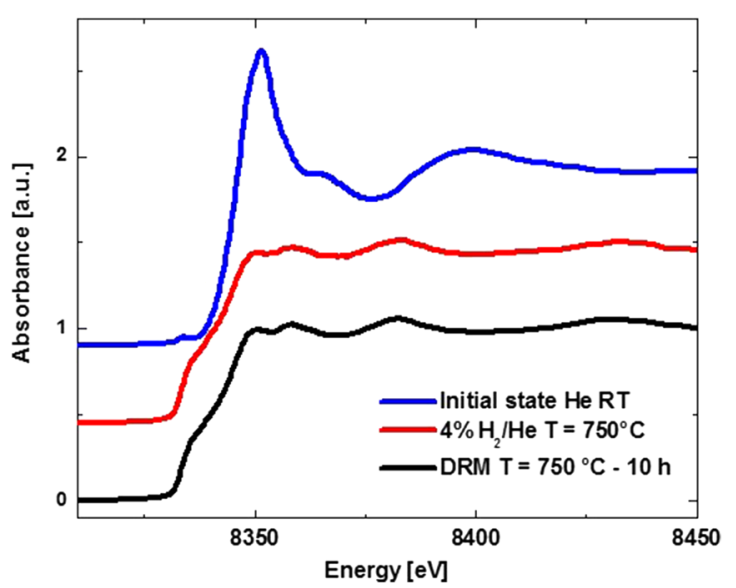

FIG. 6. Comparison of the XANES spectra in the fluorescence mode of the $\mathrm{Ni} / \mathrm{ZrO}_{2}$ catalyst as synthesized (Initial state), reduced at $750{ }^{\circ} \mathrm{C}$ at a $4 \% \mathrm{H}_{2} / \mathrm{He}$ gas flow and after $10 \mathrm{~h}$ of dry reforming reaction.
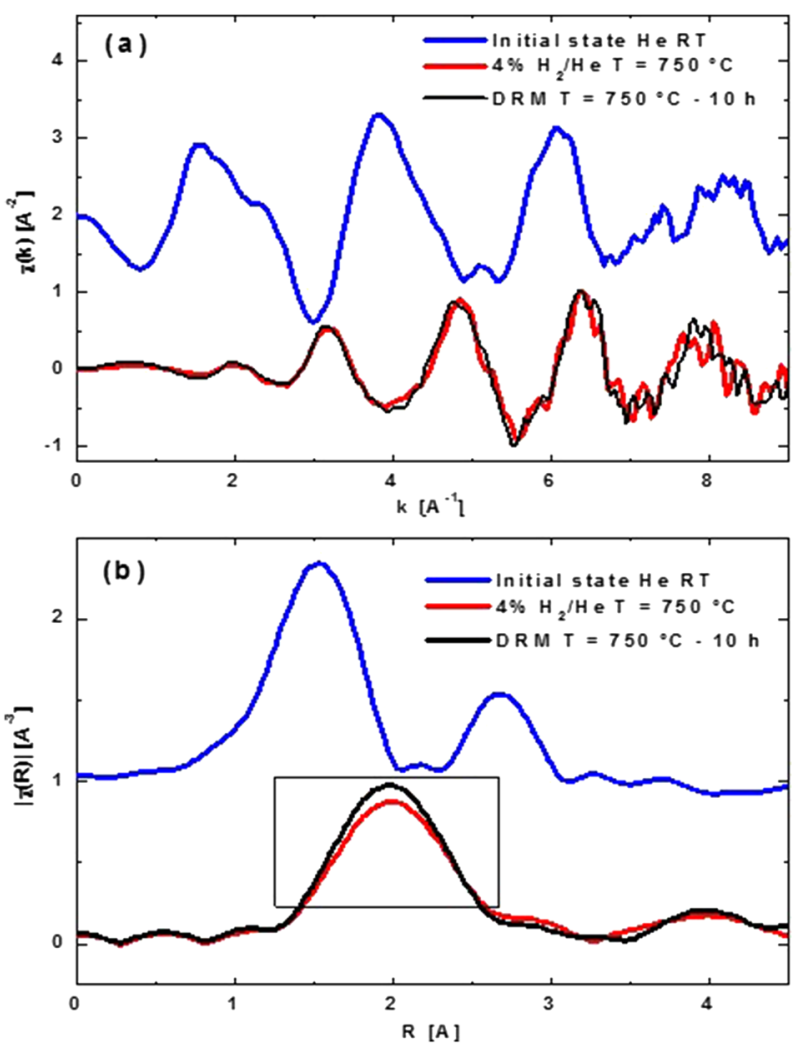

FIG. 7. Comparison of the EXAFS $\mathrm{k}^{2} \cdot \chi(\mathrm{k})$ functions (a) and their related Fourier transforms (b) for the $\mathrm{Ni} / \mathrm{ZrO}_{2}$ catalyst as synthesized, reduced at $750{ }^{\circ} \mathrm{C}$ with a $4 \% \mathrm{H}_{2} / \mathrm{He}$ gas flow and after $10 \mathrm{~h}$ of dry reforming reaction.

This is further confirmed by examining the EXAFS spectra and their corresponding Fourier transforms (Fig. 7), which indeed display two scattering paths that are easily attributed to an oxygen and a nickel shell.

After the reduction of the catalyst with a $4 \% \mathrm{H}_{2} / \mathrm{He}$ gas flow, the XANES spectrum depicts an increase in the preedge peak and the disappearance of the white line previously observed with the starting material, indicating the reduction of nickel on the catalyst.

After switching the effluent to a DRM reaction mixture, XANES and EXAFS spectra were taken at regular intervals for $10 \mathrm{~h}$. Qualitative assessment after $10 \mathrm{~h}$ of reaction of the $\mathrm{Ni} / \mathrm{ZrO}_{2}$ catalyst shows that no significant changes in the Ni K-edge were observed and that only a single $\mathrm{Ni}-\mathrm{Ni}$ scattering path was observed. A slight change in the amplitude of the Fourier transform (FT) after $10 \mathrm{~h}$ (Fig. 7) could indicate an increase in the particle size or a decrease in disorder.

\section{CONCLUSION}

We describe a new high-temperature reaction cell for XAS operando characterization. The XAS reaction cell was developed for the study of heterogeneous catalysis by transmission and fluorescence detection modes. In addition, the combination with mass spectrometry for monitoring the gas composition in real time offers a powerful tool for simultaneous characterization of a catalyst and the measurement of its catalytic activity. 
The XAS reaction cell was tested and validated in the dry reforming of methane reaction by studying a $\mathrm{Ni} / \mathrm{ZrO}_{2}(0.4$ wt. $\% \mathrm{Ni}$ ) catalyst under realistic working conditions $\left(750^{\circ} \mathrm{C}\right)$ and comparing it with the catalytic results obtained using a conventional dynamic microreactor at the same conditions. The oven of the reaction cells is able to heat up to $1000^{\circ} \mathrm{C}$ and ensures a homogeneous temperature profile along the catalytic bed which is important to the study of catalysts under operando conditions.

After validation, our new high-temperature reaction cell was successfully used in the operando XAS characterization of a low-loading monometallic $\mathrm{Co} / \mathrm{ZrO}_{2}$ and $\mathrm{Ni} / \mathrm{ZrO}_{2}$ and bimetallic $\mathrm{CoNi} / \mathrm{ZrO}_{2}$ catalysts in the DRM at $750{ }^{\circ} \mathrm{C}$. Operando XAS measurements confirmed that the Co catalyst was progressively oxidized from the surface to the bulk during the reaction, whereas $\mathrm{CoNi}$ and $\mathrm{Ni}$ remained relatively reduced during the DRM. ${ }^{30}$ This demonstration highlights the successful use of our setup for real-time monitoring of the catalyst evolution under operando DRM conditions, which is necessary for in-depth and accurate studies of structure-activity relationship.

\section{SUPPLEMENTARY MATERIAL}

See supplementary material to find the pictures of the machined glassy carbon reactor and heating and insulating elements, the validation of the XAS reaction cell in the transmission detection mode, a diagram of the complete setup, and pictures of the gas distribution system.

\section{ACKNOWLEDGMENTS}

We thank Dr. Bedour AlSabban for the assistance with the preparation method of the sample.

${ }^{1}$ S. R. Bare and T. Ressler, "Characterization of catalysts in reactive atmospheres by X-ray absorption spectroscopy," in Advances in Catalysis, 1st ed. (Elsevier, Inc., 2009), Chap. 6.

${ }^{2}$ B. R. Fingland, F. H. Ribeiro, and J. T. Miller, Catal. Lett. 131, 1 (2009).

${ }^{3}$ Y. Iwasawa, K. Asakura, and M. Tada, XAFS Techniques for Catalysts, Nanomaterials, and Surfaces (Springer International Publishing AG, Switzerland, 2017).
${ }^{4}$ J.-D. Grunwaldt, M. Caravati, S. Hannemann, and A. Baiker, Phys. Chem. Chem. Phys. 6, 3037 (2004).

${ }^{5}$ F. W. Lytle, P. S. P. Wei, R. B. Greegor, G. H. Via, and J. H. Sinfelt, J. Chem. Phys. 70, 4849 (1979).

${ }^{6}$ See www.exafsco.com for details about commercial XAS cells.

${ }^{7}$ S. Hannemann, M. Casapu, J. D. Grunwaldt, P. Haider, P. Trüssel, A. Baiker, and E. Welter, J. Synchrotron Radiat. 14, 345 (2007).

${ }^{8}$ D. Bazin, A. Triconnet, and P. Moureaux, Nucl. Instrum. Methods Phys. Res., Sect. B 97, 41 (1995).

${ }^{9}$ B. S. Clausen and H. Topsøe, Catal. Today 9, 189 (1991).

${ }^{10}$ G. Sankar, P. A. Wright, S. Natarajan, J. M. Thomas, G. N. Greaves, A. J. Dent, B. R. Dobson, C. A. Ramsdale, and R. H. Jones, J. Phys. Chem. 97, 9550 (1993).

${ }^{11}$ N. E. Tsakoumis, A. Voronov, M. Ronning, W. Van Beek, O. Borg, E. Rytter, and A. Holmen, J. Catal. 291, 138 (2012).

${ }^{12} \mathrm{See}$ http://fmb-Oxford.com for details about the FMB-Oxford heating gas blower.

${ }^{13}$ J.-D. Grunwaldt, N. van Vegten, A. Baiker, and W. van Beek, J. Phys.: Conf. Ser. 190, 12160 (2009).

${ }^{14}$ W. van Beek, O. V. Safonova, G. Wiker, and H. Emerich, Phase Transitions 84, 726 (2011).

${ }^{15}$ S. J. Tinnemans, J. G. Mesu, K. Kervinen, T. Visser, T. A. Nijhuis, A. M. Beale, D. E. Keller, A. M. J. Van Der Eerden, and B. M. Weckhuysen, Catal. Today 113, 3 (2006).

${ }^{16}$ G. L. Chiarello, M. V. Dozzi, M. Scavini, J. D. Grunwaldt, and E. Selli, Appl. Catal., B 160-161, 144 (2014).

${ }^{17}$ J. D. Grunwaldt, S. Hannemann, C. G. Schroer, and A. Baiker, J. Phys. Chem. B 110, 8674 (2006).

${ }^{18}$ S. R. Bare, N. Yang, S. D. Kelly, G. E. Mickelson, and F. S. Modica, Catal. Today 126, 18 (2007).

${ }^{19}$ See https://echa.europa.eu/substance-Information/-substanceinfo/100.028. 318 for ECHA-(European Chemicals Agency).

${ }^{20}$ A. Bansode, G. Guilera, V. Cuartero, L. Simonelli, M. Avila, and A. Urakawa, Rev. Sci. Instrum. 85, 84105 (2014).

${ }^{21}$ D. Testemale, R. Argoud, O. Geaymond, and J. L. Hazemann, Rev. Sci. Instrum. 76, 043905 (2005).

${ }^{22}$ V. F. Kispersky, A. J. Kropf, F. H. Ribeiro, and J. T. Miller, Phys. Chem. Chem. Phys. 14, 2229 (2012).

${ }^{23}$ S. Wang, G. Q. Lu, and G. J. Millar, Energy Fuels 10, 896 (1996).

${ }^{24}$ A. J. Brungs, A. P. E. York, J. B. Claridge, M. Carlos, and M. L. H. Green, Catal. Lett. 70, 117 (2000).

${ }^{25}$ See http://www.htw-gmbh.de/index.php5?lang=en\&nav0=0 for Hochtemperatur-Werkstoffe $(\mathrm{GmbH})$

${ }^{26}$ K. Tamura, M. Inui, and S. Hosokawa, Rev. Sci. Instrum. 66, 1382 (1995).

${ }^{27}$ B. Fang, N. K. Chaudhari, M.-S. Kim, J. H. Kim, and J.-S. Yu, J. Am. Chem. Soc. 131, 15330 (2009).

${ }^{28}$ F. de Groot, G. Vankó, and P. Glatzel, J. Phys.: Condens. Matter 21, 104207 (2009).

${ }^{29}$ D. Cabaret, A. Bordage, A. Juhin, M. Arfaoui, and E. Gaudry, Phys. Chem. Chem. Phys. 12, 5619 (2010).

${ }^{30}$ B. AlSabban, L. Falivene, S. M. Kozlov, A. Aguilar-Tapia, S. Ould-Chikh, J.-L. Hazemann, L. Cavallo, J.-M. Basset, and K. Takanabe, Appl. Catal., B 213, 177 (2017). 